UDC 304.2:616.01/-099

DOI: $10.17223 / 24109266 / 9 / 9$

\title{
THE ROLE OF NATURAL LANGUAGES AS LINGUA FRANCAS IN THE COURSE OF HUMAN HISTORY
}

\author{
V.M. Smokotin, G.I. Petrova, S.K. Gural \\ National Research Tomsk State University (Tomsk, Russian Federation) \\ E-mail: vladimirsmokotin@yandex.ru; seminar2008@mail.ru; gural.svetlana@mail.ru
}

\begin{abstract}
The article considers the use of natural rather than constructed (or artificial) languages as means of international communication in overcoming interlingual and intercultural barriers. The authors seek answers to the question whether natural languages have proved their effectiveness as tools of international communication. Another important line of research is determining the factors that have played a decisive role in the choice of some natural languages as lingua francas in the history of international relations. Finally, the authors explore the factors that have contributed to the transformation of English from one of the most widespread natural languages into the language of global communication.
\end{abstract}

Keywords: lingua franca; natural languages; interlingual and intercultural communication; globalization.

\section{Introduction}

The ongoing globalization of the worldwide economic, political, cultural, scientific and other relations has brought about a considerable increase of international contacts and called forth a real need for a common language of global communication for overcoming interlingual and intercultural barriers separating humanity and interfering with the growth of international exchanges. However, an interest in a universal language of humankind arose long before any practical need emerged in worldwide communication, which would require the choice of a global rather than regional lingua francas.

The interest in finding a universal language resulted in numerous projects aimed at creating artificial or constructed languages, some of which achieved a wide recognition and even reached the level of international organizations, including the League of Nations [1]. But while the quest for a common constructed language has apparently failed, it highlighted the role of natural languages in erecting bridges between speech communities, and eventually, at the turn of the $20^{\text {th }}$ century, one of the natural languages English - acquired the status of the global language. In natural languages, the communicative function serves its purpose primarily within a given ethnic group. Historic contacts of different regions and countries, however, have spread its action to the arena of international relations. 
In this paper, we will consider the arguments of "natural languages versus conlangs (constructed languages) in choosing the language of international communication, and we will first turn to the experience of using natural languages for overcoming interlingual and intercultural barriers. The aim of the paper is investigating the following questions: 1) what factors have caused some natural languages to assume the role of regional lingua francas in the history of international relations? 2) have natural languages proved effective as tools of international communication?

\section{Methodology}

The evolution of the universal language concept from the notion of the "perfect language" to the "global lingua franca" has raised important questions concerning the choice of the language of common communication and advantages as well as disadvantages in using natural rather than constructed languages in overcoming linguistic barriers between different speech communities. Leau and Couturat in their "Histoire de la Langue Universelle" published in early $20^{\text {th }}$ century expressed their confidence that humankind was on the threshold of finding the universal language of the world and that it would be one of the most popular artificial (or constructed) languages, like Esperanto [2].

As constructed languages failed to get the support they needed to assume the level of true lingua francas even on a regional level, at the turn of the $20^{\text {th }}$ century, one of the most widespread natural languages, English, emerged as the global lingua franca - the vehicular language in all spheres of international exchange. Abram De Swaan explained the changes in the global language system resulting in English becoming the first language in history with the status of the language of worldwide communication by its highest communicative potential (so called "Q-value") [3]. Even before English achieved its global status, linguists and politicians opposing the cultural domination of English argued that accepting English as the global means of communication would lead to the eventual loss of cultural and linguistic diversity by the end of the $20^{\text {th }}$ century. The most notable critic of English as the language of linguistic and cultural domination, Robert Phillipson, in his 1992 book "Linguistic Imperialism" defined English linguistic imperialism as "the dominance asserted and retained by the establishment and continuous reconstitution of structural and cultural inequalities between English and other languages" [4].

Phillipson's theory of linguistic imperialism has failed to win much support in the academic world, but his warnings about the consequences of linguistic and cultural domination were addressed in many works dedicated to research into the phenomenon of English as the global language. David Crystal, while not sharing Phillipson's views on English linguistic imperial- 
ism, has considered, nevertheless, the problems of "the dangers of a global language" and "language death" [5]. Thus, it appears there are different approaches to what can be a language of common communication or lingua franca. Even more confusing is the role of natural languages in the choice of means of international and universal communication. Finally, there is the question of why English rather than any artificial or natural language has acquired the status of the global language. In this paper, we will analyze the role of natural languages in building bridges between speech communities as well the reasons why natural languages prove to be more effective than artificial ones as means of overcoming linguistic and cultural barriers.

\section{Findings and Analysis}

In the historical epochs preceding the emergence of the capitalist mode of production and the industrial revolution, which led to the internationalization of trade flows and comparative growth of interlingual and intercultural contacts, international contacts in the times of peace were limited to diplomatic relations, a relatively limited trade exchange and cultural as well as scholarly connections of the enlightened elite. The exclusive elitism of those relations, particularly diplomatic ones, shifted linguistic problems of international communications to the background since the subjects of those relations were representatives of the privileged circles, whose education included the study of the most important languages.

In Europe, following the decline and fall of the Western Roman Empire, throughout the Middle Ages and the Renaissance, the classical Latin was a universally recognized language of international communication and scholarship. In the $18^{\text {th }}$ century, with the emergence of nation states, Latin was gradually ousted, and national languages came into use even in international relations. What made Latin a European Lingua Franca over a long period of time, lasting from the $5^{\text {th }}$ to the $18^{\text {th }}$ centuries? Latin was the most rational choice of a common means of communication in Europe after the collapse of the Western Roman Empire since it had practically no competitors with the exception of Koine Greek, a regional lingua franca in the Eastern Roman Empire. The domination of Latin, as the language based on the political, military and cultural power of Rome, pushed the numerous local languages to the background, deprived them of any development into codified standards, and eventually led to Europe losing most of its linguistic diversity. As for Koine Greek, its use was limited to the Hellenistic world following the Battle of Corinth in $146 \mathrm{BC}$, which marked the beginning of the Roman domination in Greek history. Latin was not only the dominant language of the Roman Empire, but continued as the official language of the Byzantine Empire after the fall of the Western Roman Empire, until the Reign of Heraclius (AD 610-641), when it was finally replaced with Greek. 
In the $18^{\text {th }}$ century, French emerged as the language of educated elite in Europe, and it also replaced Latin as the language of diplomatic relations. The domination of the French language and culture in Europe began with the epoch of Louis XIV (le grand siècle) and reached its peak in the Age of Enlightenment, when France became a leading center of academic, intellectual and cultural life, a source of progressive ideological movements and a center of major scientific discoveries. The Age of Enlightenment, as one of the key epochs in the history of the European culture, began in France, where it became known as "le siècle des lumières", and spread to the rest of Europe. The French enlighteners Voltaire, Montesquieu, Rousseau, Diderot and others became the movers and shakers of the times. The influence of their ideas, based on criticism of the contemporary traditional institutes, customs, morals, and their belief in nature and human progress played an important role in strengthening the positions of French as the language of common communication of upper classes and the enlightened circles of Europe.

As Hackett Lewis writes, "After the Peace of Utrecht" (1713), the Enlightenment was largely a French Phenomenon... By 1750, the salonnieres, their salons, and the philosophes had made France once again the intellectual center of Europe" [6]. Bilingualism of Europe's upper classes, which was established in the $18^{\text {th }}$ century, allowed the European elite to communicate without interpreters with representatives of power structures and educated people in any other European country and, at the same time, to retain their national languages, which by that time had acquired a literary form and were no longer regarded as "vulgar" or "low". Russian nobility and intelligentsia made no exception. Conversations in French in the literary salons of Russian aristocracy described in "War and Peace" by Leo Tolstoy are no literary fiction but correspond with reality. Russian nobility, when communicating among themselves and with noble Europeans, spoke in French, and even preferred the "language of Europe" to their native language in oral and written intercourse with people of their own circle if culture and arts made the subject of their conversations.

Alexander Pushkin in his letter written in French to Pyotr Chaadayev, a well-known Russian thinker and publicist, wrote: "Mon ami, je vous parlerai la langue de l'Europe, elle m'est plus familière que la nôtre, et nous continuerons nos conversations commencées jadis à Sarsko-Sélo et si souvent interrompues" [7]. France's loss of its unquestionable leadership in the political, economic, scientific and technological fields during the $19^{\text {th }}$ and $20^{\text {th }}$ centuries brought about a gradual weakening of the positions of French as a language of international relations both in Europe and in the whole world with the exception of the global community of French speaking peoples former French colonies, which after achieving independence from France adopted the language of the former metropolis as their official language. 
After World War II, the political and economic cooperation on a global scale resulted in a gradual removal of traditional barriers interfering with international exchange in all spheres of activity, starting with the international trade and ending with the organization of mass travel and tourism. The absence of a language of universal communication, however, presents an almost insurmountable barrier to interpersonal contacts in the conditions of globalization, when interlingual and intercultural communication becomes the spirit of the times.

However, as English spread still further around the world in the second half of the $20^{\text {th }}$ century, fears were voiced about the gradual loss of linguistic and cultural diversity due to its replacement of national and ethnic languages and cultures. The development of European countries, with few exceptions, along the road of forming nation-states with one official language on the basis of the language variant of the dominant ethnic group elite furthered the political and economic unification of the nation-states, creation of the common national culture and unhindered development of all aspects of social life, but, at the same time, erected obstacles for establishing multilateral international connections and realization of policies of mutual understanding and cooperation necessary for maintaining lasting peace. The centuries-old period of international relations among nation-states has brought about the creation of the societal mentality that regards monolingualism and monoculturalism as normal phenomena, and multilingualism as an exception or a deviation from the norm $[8: 1 ; 9 ; 10]$. We will return to the question of English as the global lingua franca and the threat to ethnocultural identities later, and now we will try to answer the question of how English assumed the role of the international language in a number of important spheres despite fierce resistance put up by some academics and politicians to enacting any corresponding international legislation.

A pressing need for a language of worldwide communication not only in the field of diplomatic relations and political collaboration, but in all the other fields was felt yet long before the emergence of the information society and globalization of world economy. Effective communication in international maritime navigation would be exceedingly hampered without adopting a common language of communication and special language training of crews for overseas voyages. Therefore, it was the international maritime navigation that became the first area of international contacts where naval powers recognized a need for the common language of communication.

Since by the middle of the $19^{\text {th }}$ century the British Empire had emerged as the biggest naval power, which reflected in the poetic metaphor "Britannia rules the waves", the English language became the international language of marine navigation yet long before the international legislation regulating international seafaring was passed, and the vast expanses of the Seven Seas became the world's first global language area. The role of Eng- 
lish as the common language of international marine communication was later confirmed in international law. In 1973, the Maritime Safety Committee of the International Maritime Organization (IMO) agreed at its $27^{\text {th }}$ session that "where language difficulties arise, a common language should be used for navigational purposes and that language should be English" [11: 1]. Following this agreement, IMO experts developed the Standard Marine Navigational Vocabulary (SMNV), which was adopted in 1977 and amended in 1985. The further work on the Dictionary in order to develop a more comprehensive standardized safety language covering all major safety-related verbal communications resulted in creation and adoption by the IMO Assembly in November 2001 of the Draft Standard Marine Communication Phrases (SMCP) [Ibid.: 3]. According to the International Convention on Standards adopted in 1978 and reviewed in 1995, "the ability to understand and use the SMCP is required for the certification of officers in charge of a navigational watch on ships of 500 gross tonnage or more" [Ibid.: 3-4].

Civil aviation, unlike marine navigation, is a comparatively new field of activities in ensuring transport of passengers, baggage, cargo and mail. In the second half of the $20^{\text {th }}$ century it turned into one of the largest sectors of the world economy with the well-developed infrastructure. In the age of globalization and digital technologies, aviation transport makes up 40 percent of the world trade, while the weight of the transported cargo does not exceed two percent of the general volume of transported cargo in the world, which is explained by the high value of new goods in the area of information technologies compared to the dimensions and weight [12]. The growth of world economy and international trade in the post-war period as well as a continuous increase of the flow of passengers, which, according to the World Trade Organization had been growing on the average annually by 9 percent in the period from 1960 to 2000 [13], testifies to the fact that air transport in general and the international passenger air transport in particular play a decisive role in the process of international integration and affect the other sectors of world economy. As in the case of marine navigation, a need for a common language in international air transport has led to passing international legislation, in which the importance of using a common language is substantiated by the requirements of ensuring clear and unambiguous communication between pilots and systems of air traffic control with the aim of avoiding errors in communication.

The realization of a need for a common language for communication in international civil aviation practices and an introduction by legislation of standard phraseology as well as heightening demands to the language skills of pilots took place in the period of globalization processes acceleration, when failures in communication between pilots and ground control due to considerably higher cargo and passenger air transport flows became more frequent. In the pre-war period of the civil aviation development and during 
the first decades after World War II, English was widely used as a de facto language of international air communication, but, in the absence of universally accepted international legislation, uncertainty in choosing a language of communication resulted from differences in language policies of aviation companies and national governments.

Lax English language skills requirements in certifying pilots, and lack of correspondence between national legislations concerning civil aviation became a formidable obstacle not only for a natural growth of international exchanges with the use of air transport, but also for ensuring the means of protecting the lives of passengers and crews. A turning point in the history of using a common language in international civil aviation proved to be the air crash of 1977 on the runway of the Los Rodeos airport on the island of Tenerife, which went down in history as the Tenerife airport disaster, the deadliest accident in aviation history with total fatalities of 583. The collision of two Boeings 747 aircraft was explained by a concurrence of unfavorable circumstances but the main cause of the collision was a breakdown in language communication (see "The Deadliest Plane Crash" [14]). As in the case of the sinking of the Titanic, which manifested the importance of coordinating national systems of marine navigation in development and adoption of international legislation with the aim to safeguard lives on the seas, including measures to improve the quality of communication with the use of a common language, so after the Tenerife airport disaster the International Civil Aviation Organization, ICAO, undertook a number of measures in order to prevent accidents in aviation practices due to failures in communication. In the early 1980s, the ICAO published a reviewed variant of the English language standard phraseology used in communication of pilots and air traffic controllers so as to exclude the repetition of errors due to ambiguity of some phraseology used before [15].

At the turn of the $20^{\text {th }}$ century, when requirements to standardization and harmonization in international civil aviation increased against the background of deepening and widening globalization processes, the ICAO took the road of introducing requirements to English language skills of pilots and air traffic controllers with mandatory certification. The ICAO Language Proficiency Requirements (LPRs), developed by a special group of ICAO experts, established standards that require pilots and air traffic controllers "to be able to communicate proficiently using both ICAO phraseology and plain English" [16]. New requirements emphasize the insufficiency of language training based on simplified English and a limited list of phraseology used in civil aviation. As the authors of a special Manual on the Implementation of ICAO Language Proficiency Requirements pointed out, no set of phrases can describe all possible situations and response reactions. They stated that "the most critical need for plain language proficiency arises during urgent or emergency situations, when in- 
adequate language proficiency simply becomes another barrier to the successful conclusion of a flight" [17]. New ICAO Language Proficiency Requirements graded English language performance on a scale from 6 (highest) to 1 (lowest), and ruled that pilots and air traffic controllers and others who use English in communication on international routes must be at Level 4 (Operational) or above. Those who fail to demonstrate proficiency at Level 4 may not be licensed to operate on international routes. If a pilot or controller achieves Level 4 once, "further English training may be needed to maintain this level of proficiency" [16].

However, if a need for a common language in marine navigation and international civil aviation is obviated, first of all, by striving for enhancing safety in situations, when failures in overcoming linguistic and cultural barriers may lead to loss of human lives, a need for a common language in all other areas of economic, political, cultural, scientific and educational life in the period of globalization is determined by purely practical considerations of unhindered development based on the growing international contacts and cooperation in the corresponding areas, which are made considerably more difficult in conditions of linguistic and cultural isolation and the absence of a universally accepted language of worldwide communication. The tempos of globalization at the start of the $21^{\text {st }}$ century outstripped the international legislative activities in the question of accepting a language of global communication. While academics and politicians are engaged in a search for the ways of solving the problem of linguistic and cultural communication in the world, where national boarders are growing ever more transparent for cargo and passenger flows, English is in the process of acquiring the traits of the de facto global lingua franca used as the default language in all situations of international exchange. Apart from traditional areas where the English language started to dominate yet in the 1950s-1960s, such as business, commerce, international tourism, popular culture (particularly music), since the 1980s, the penetration of English as the language of worldwide communication into science and medicine, informatics and telecommunications, international standards etc. increased dramatically. The great importance of the English language in the presentday world may be judged on the basis of the commodity production economic category of "supply and demand".

Globalization processes in the world economy have led to the fact that many notions which have never been associated with commoditymonetary relations, such as, for example, inborn abilities, education and acquired qualifications are regarded by economists at present as "human capital", that is a measure of capacity embodied in a person to yield a profit [18]. Increasingly, politicians and educators around the world recognize the priority of English language skills as a basic key competence of the knowledge society. As Eurostat reports, English teaching in secondary ed- 
ucation [in Europe] is now almost universal, reaching close to 100 percent [19]. Teaching English as a second and foreign language (ESL, EFL) has turned into a multibillion business. Thus, the total ELT (English Language Teaching) market in native English speaking countries already in early $21^{\text {st }}$ century was worth over US\$ 5 billion in terms of total student expenditure, with the largest two destinations in terms of incoming bilingual travel being the UK and the USA [2: 27]. The largest single ELT market in the world is China, where English teaching industry is estimated US\$ 4.5 billion, which is commensurate with the total ELT market in native English speaking countries [20]. According to China Daily, more than 300 million Chinese are studying English, and "it is theoretically possible that the number of English speaking Chinese will outnumber the populations of all English speaking countries in the world, combined" [21]. As the economic observer S. Hipsher points out, "the worldwide ESL industry is an industry and is shaped by market forces and language school owners... and educational managers need to take financial as well as educational matters into consideration when making all types of decisions" [22]. The progress in new ICT technologies has allowed increasing considerably the number of English language learners in the world due to Internet training in the online mode. Native English speakers used as language teachers can carry out the teaching process without moving over to the countries of their students' residence, before a virtual English language classroom of 800 million students in the entire world [23].

\section{Discussion}

While natural languages have been successfully used throughout human history as lingua francas, there are still views expressed mostly by the Esperanto community and followers of the theory of linguistic imperialism by Robert Phillipson about their ineffectiveness as means of universal communication as well as unfairness of using them connected with their cultural non-neutrality. The authors of the Prague Manifesto by the UEA (Universal Esperanto Association) issued in 2003 stated: "Neither the worldwide use of a few national languages, nor advances in communication technology, nor the development of new methods of language teaching is likely to result in a fair and effective language order... which we hold to be essential" (Prague Manifesto, 2003. UEA Universala Esperanto-Asocio (http://www.uea.org). Phillipson claims that English has become the dominant international language, and its dominance "is asserted and maintained by the continuous creation of cultural inequalities between English and other languages" [4: 47].

However, even though artificial languages are culturally neutral, have much simpler grammatical structures and, therefore, are much easier to teach 
and learn, they cannot compete with natural languages in their effectiveness as means of overcoming linguistic and cultural barriers in all spheres of international communication. The experts of International Civil Aviation Organization (ICAO), comparing natural and constructed languages, state that "there is no 'form of speech' more suitable for human communication than natural language. Artificial languages... have had little impact in any sphere even decades after their introduction. Computer-aided voice recognition and translation technologies remain unproven, especially in the context of the demand for reliability in aviation. As all other options fall short, natural language continues to be the most reliable and efficient form of human communication" [17: 1-3].

The chief advantage of natural over artificial languages is in an extraordinary wealth and flexibility of their word stock, which is continuously renewed and replenished in the process of society's development and emergence of new phenomena that require from the language as a means of human communication the forming of new linguistic signs (words) and their combinations (structures). On the other hand, the practical value of artificial languages is considerably lowered due to limitations in the spheres of their use and insufficient elaboration of their word stock to serve various areas of activity. Language forms, including natural languages' word stocks, are products created by the language speakers themselves, unlike artificial languages, which have a rather limited number of speakers to ensure normal functioning of the languages, particularly in the periods of society's revolutionary social changes in political, economic, scientific and cultural life. The lexical wealth of natural languages makes possible achieving mutual understanding in situations when normative standard set of expressions used in international communication is insufficient due to the non-standard nature of the given situation.

In this connection, Victoria Fromkin has drawn our attention to an important trait of human language that makes natural languages irreplaceable in human practices regardless of political or economic considerations - the creative aspect of human language, which is manifested in the ability of the speaker to combine linguistic units to form an infinite set of grammatically correct sentences, most of which represent new sentences that have never been used before. She also pointed out that natural languages are "vigorous, dynamic and constantly changing" [24: 16].

\section{Conclusion}

Thus, the most important factors that have turned natural languages into lingua francas are based mostly on the political, economic and cultural power of the imperial or national entities which used these languages. As the history of international language shows, natural languages have proved high- 
ly effective as tools of international communication. Latin, and then French were used over centuries as regional lingua francas of Europe, while English at the turn of the $20^{\text {th }}$ century acquired the status of the Global Lingua Franca due to its superior communicative value, the result of leading positions of the English speaking countries in economic, scientific, technological and cultural spheres.

\section{References}

1. Smokotin, V.M., Petrova, G.I. (2015). The Quest for a Universal Language throughout Human History. Procedia - Social and Behavioral Sciences. 200. pp. 107-113.

2. Leau, L., Couturat, L. (1903). Histoire de la Langue Universelle. Kessinger Publishers LLC (facsimile reprint in 2000).

3. De Swaan, A. (2001). Words of the World. The Global Languge System. Cambridge: Polity.

4. Phillipson, R. (1992). Linguistic Imperialism. Oxford: Oxford University Press.

5. Crystal, D. (1997). English as a global language. Cambridge University Press.

6. Lewis, H. (1992). The Age of Enlightenment. The European dream of Progress and Enlightenment. URL: http://www.history.world.org/age_of_enlightenment.htm.

7. Pushkin, A.S. (1962). Collected works in 10 volumes. Moscow: Khudozhestvennaya Literatura. 10 .

8. Romaine, S. (1995). Bilingualism. New Jersey: Wiley-Blackwell, Hoboken.

9. Pavlenko, A. (2000). L2 influence on L1 in late bilingualism. Issues in Applied Linguistics. 11 (2). pp. 175-206.

10. Ellis, E. (2000). Monolingualism: The unmarked case. Estudios de Sociolingüistica. 7 (2). pp. 173-196.

11. (2000). IMO Standard Marine Communication Phrases. NAV 46/INF.4. 14 July 2000. 1.

12. Kasarda, J.D., Green, J. (2004). Air Cargo: Engine for Economic Development. The International Air Cargo Association. Air Cargo Forum, Bilbao, Spain. URL: www.tiaca.org/images/tiaca/PDF/TIACA-KI.pdf

13. (2007). World Trade Organization Second Review of the Air Transport Annex: Developments in the Air Transport Sector (Part III) Note by the Secretariat, document S/C/W/270/Add.2. URL: https://www.wto.org/english/tratop_e/serv_e/transport_e/review2 e.htm

14. (1977). (The) Deadliest Plane Crash. NOVA PBS. URL: www.pbs.org/wghh/.../deadliestplane-crash/

15. Robertson, F.A. (2007). Aviation English comes of Age. ICAE. URL: www.icae.net/assets/documents/Closing Address

16. (2003). ICAO, Language Proficiency Requirements for Pilots and Air Traffic Controllers. URL: http://www.englishforaviation.com/ICAO -requireents.php

17. (2004). ICAO. Doc 9835 - AN/453. Manual on the Implementation of ICAO Language Proficiency Requirements. Montreal: ICAO.

18. Fischer, S., Dornbusch, R., Schmalensee, R. (1987). $2^{\text {nd }}$ edition. Economics. New York: McGraw Hill.

19. (2013). Eurostat. The EU in the World 2013. URL: https://www.ec.europa.eu/eurostat

20. Tan, M. (2011). The Great Pretenders: China's "unfire-able" English teachers. URL: http://www.diaspora.chinasmack.com/.../monica-tan-the-great-pretenders

21. Whiteley, P., Xiao Xiangyi (2011). Lingua Franca. China Daily European Weekly. 2011$02-25$.

22. Hipsher, S. (2010). ESL industry analysis. How attractive to a potential teacher is the ESL industry as a whole. URL: www.ajarn.com/blogs/scott-hipsher/esl-industry-analysis/ 
23. Redman, D. (2010). How to teach online webinars. What's the multi-billion dollar ESL industry doesn't want you to know. PRWeb (9 July, 2014).

24. Fromkin, V., Rodman, R., Hyams, N. (2003). $7^{\text {th }}$ edition. An Introduction to Language. Boston, Massachusetts, USA: Thomson Wadsworth.

Resived 02.05.2017

\section{Information about the authors:}

Petrova Galina - D.Sc. (Philosophy), Professor, Faculty of Philosophy, National Research Tomsk State University (Tomsk, Russian Federation). E-mail: seminar2008@mail.ru

Smokotin Vladimir - D.Sc. (Philosophy and Culture), Professor, Faculty of Foreign Languages, National Research Tomsk State University (Tomsk, Russian Federation). E-mail: vladimirsmokotin@yandex.ru

Gural Svetlana - D.Sc. (Education), Professor, Faculty of Foreign Languages, National Research Tomsk State University (Tomsk, Russian Federation). E-mail: gural.svetlana@mail.ru 